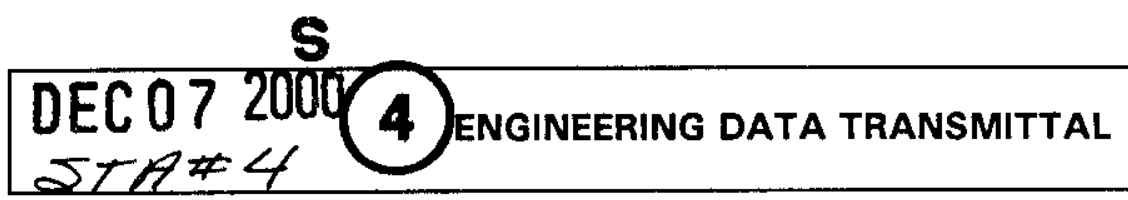

Page 1 of 1 1. EDT 630993

2. To: (Receiving Organization)

Distribution

5. Proj./Prog./Dept./Div.:

Interim Stabilization

8. Originator Remarks:

Original Revision for Release

11. Receiver Remarks:
3. From: (Originating Organization)

DST M\&R Engineering

6. Design Authority/Design Agent/Cog. Engr.:

W. E. Zuroff
4. Related EDT No.:
N/A
7. Purchase Order No.:
N/A
9. Equip./Component No.:

Saltwel1 Pumping

10. System/Bldg./Facility:

200E/200W Tank Farms

12. Major Assm. Dwg. No.:

H-14-104285

13. Permit/Permit Application No.:

$\mathrm{N} / \mathrm{A}$

14. Required Response Date:

$\mathrm{N} / \mathrm{A}$

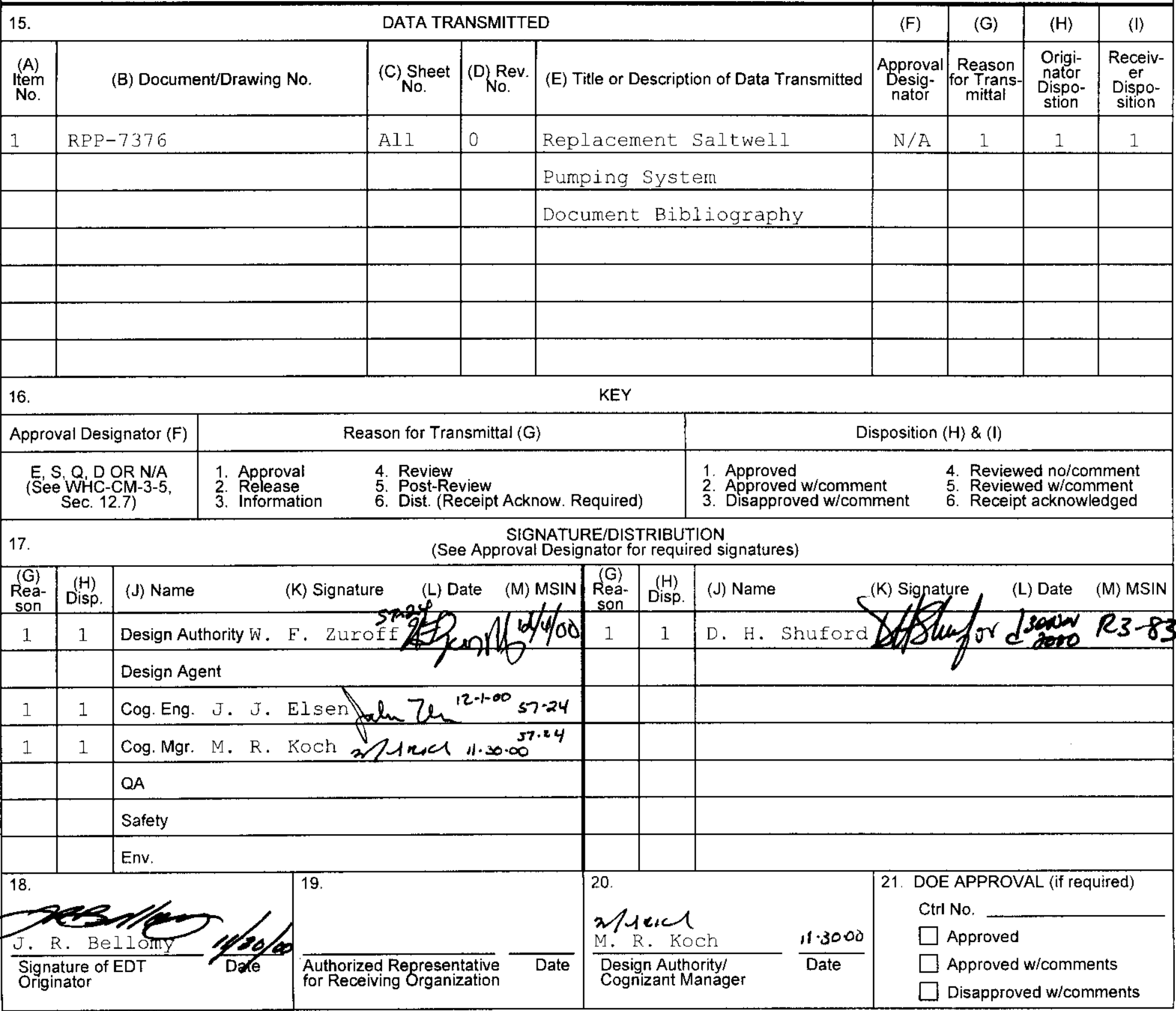

BD-7400-172-2 (10/97) 


\title{
Replacement Saltwell Pumping System Document Bibliography
}

\author{
JR Bellomy \\ CH2MHill Hanford Group, Inc. \\ E.O. BOX 1500 \\ Richland, WA 99352 \\ U.S. Department of Energy Contract DE-AC06-96RL13200

$\begin{array}{lll}\text { EDT/ECN: } 630993 & \text { UC: } 2020 \\ \text { Org Code: } 74600 & \text { Charge Code: } 113340 \\ \text { B\&R Code: } & \text { Ew3130010 } & \text { Total Pages: } 7\end{array}$

Key Words: Interim Stabilization, Saltwell Pumping, Sundyne, Engineering Documents, Bibliography

\begin{abstract}
This supporting document is prepared to identify engineering documentation prepared during the design and development of the replacement saltwell pumping system.
\end{abstract}

TRADEMARK DISCLAIMER. Reference herein to any specific commercial product, process, or service by trade name trademark, manufacturer, or otherwise, does not necessarily constitute or imply its endorsement, recommendation, or favoring by the United States Government or any agency thereof or its contractors or subcontractors.

Printed in the United States of America. To obtain copies of this document, contact: Document Control Services, P.O. Box 950, Mailstop H6-08, Richland WA 99352, Phone (509) 372-2420; Fax (509) 376-4989.
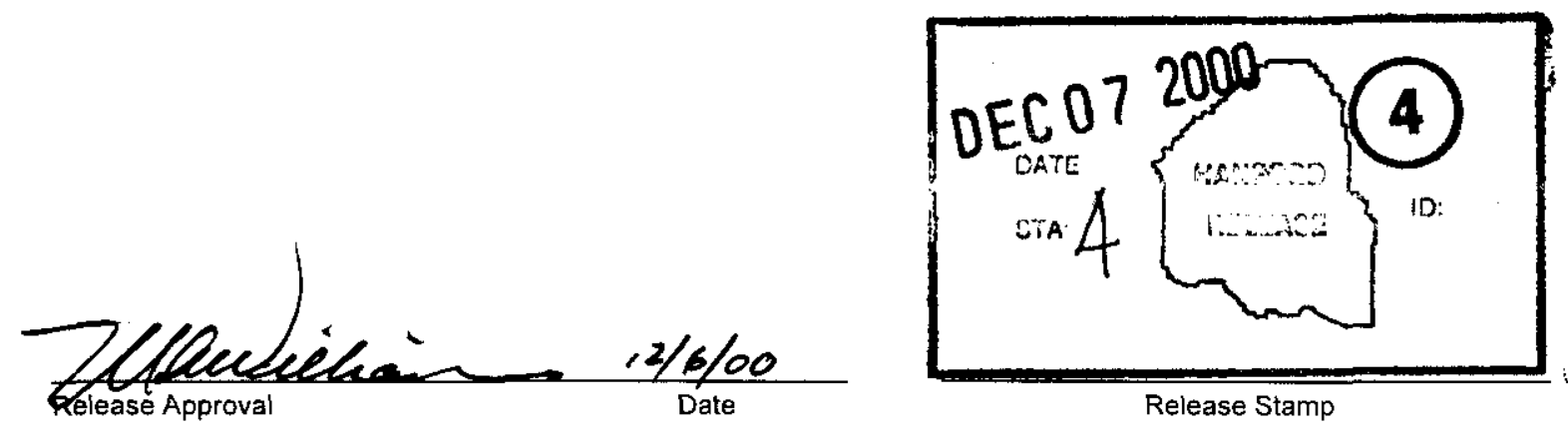

\section{Approved For Public Release}


RPP-7376

Revision 0

\section{Replacement Saltwell Pump Document Bibliography}

Prepared for the U.S. Department of Energy

Assistant Secretary for Environmental Management

\section{CH2MHILL \\ Hanford Group, Inc.}

Richland, Washington

Contractor for the U.S. Department of Energy

Office of River Protection under Contract DE-AC06-99RL14047

Approved for Public Release; Further Dissemination Unlimited 
RPP-7376

Revision 0

\section{Replacement Saltwell Pump Document Bibliography}

J. R. Bellomy

CH2M HILL Hanford Group, Inc.

Date Published

October 2000

\section{CH2MHILL \\ Hanford Group, Inc.}

P. O. Box 1500

Richland, Washington

Contractor for the U.S. Department of Energy

Office of River Protection under Contract DE-AC06-99RL14047

Approved for Public Release; Further Dissemination Unlimited 


\section{LEGAL DISCLAIMER}

This report was prepared as an account of work sponsored by an agency of the United States Government. Neither the

United States Government nor any agency thereof, nor any of their employees, nor any of their contractors, subcontractors

or their employees, makes any warranty, express or implied, or assumes any legal liability or responsibility for the

accuracy, completeness, or any third party's use or the results of such use of any information, apparatus, product, or process disclosed, or represents that its use would not infringe privately owned rights. Reference herein to any specific commercial product, process, or service by trade name, trademark, manufacturer, or otherwise, does not necessarily constitute or imply its endorsement, recommendation, or favoring by the United States

Government or any agency thereof or its contractors or subcontractors. The views and opinions of authors expressed herein do not necessarily state or reflect those of the United States Government or any agency thereof.

Printed in the United States of America 


\section{Replacement Saltwell Pump Document Bibliography}

\section{Introduction:}

This document bibliography is prepared to identify engineering documentation developed during the design of the Replacement Saltwell Pumping System. The bibliography includes all engineering supporting documents and correspondence prepared prior to the deployment of the system in the field. All documents referenced are available electronically through the Records Management Information System (RMIS).

Major components of the Replacement Saltwell Pumping System include the Sundyne Canned Motor Pump, the Water filter Skid, the Injection Water Skid and the Backflow Preventer Assembly. Drawing H-14-104498 provides an index of drawings (fabrication details, P\&IDs, etc.) prepared to support development of the Replacement Saltwell Pumping System.

Specific information pertaining to new equipment can be found in Certified Vendor Information (CVI) File 50124. This CVI file has been established specifically for new equipment associated with the Replacement Saltwell Pumping System.

\section{Bibliography:}

\section{Supporting Documents:}

RPP-6756, 2000, Evaluation of Pump Alternatives for Saltwell Pumping, CH2M HILL Hanford Group, Inc., Richland Washington.

RPP-6883, 2000, Evaluation of Failed Crane Chempumps Used During Saltwell Pumping, CH2M HILL Hanford Group, Inc., Richland Washington.

RPP-6914, 2000, Replacement Saltwell Pump Cost Evaluation, CH2M HILL Hanford Group, Inc., Richland Washington.

RPP-6954, 2000, Hazard Evaluation for a Saltwell Centrifugal Pump Using Service Water for Lubrication and Cooling, CH2M HILL Hanford Group, Inc., Richland Washington.

RPP-6997, 2000, Replacement Saltwell Pump Functions and Requirements, CH2M HILL Hanford Group, Inc., Richland Washington. 


\section{Supporting Documents, Continued}

RPP-7197, 2000, Replacement Saltwell Pump Design Calculations, CH2M HILL Hanford Group, Inc., Richland Washington.

RPP-7377, 2000, Replacement Saltwell Pumping System Master Equipment List, CH2M HILL Hanford Group, Inc., Richland Washington.

\section{Correspondence:}

DeLozier, M. P., 2000, CONTRACT NUMBER DE-AC06-99RL14047; Proposed Authorization Basis Changes for the New Saltwell Pump Design, CHG Letter CHG-0004856 R1 with attachments, From M. P. DeLozier (CHG) to H. L. Boston, Manager (ORP), dated October 12, 2000.

Boston, H. L., 2000, CONTRACT NO. DE-AC27-99RL14047, Approval of Authorization Basis (AB) Amendment for the New Saltwell Pump Design, ORP Letter 00-SHD-1 14 with attachments, From H. L. Boston (ORP) to M. P. DeLozier, (CHG), dated November 19, 2000). 
RPP-7376, REV 0

\section{DISTRIBUTION}

\section{Onsite}

U.S. Department of Energy

Richland Operations Office

DOE Public Reading Room

$\mathrm{H} 2-53$

1

Pacific Northwest National Laboratory

Hanford Technical Library

P8-55

3

Lockheed Martin Services, Inc.

Central Files

B 1-07

Document Processing Center

A3-94

13

CH2MHill Hanford Group, Inc

J. R. Bellomy

R3-83

M. D. Gerken

R3-83

K. R. Ellingson

S7-24

J. J. Elsen

S7-24

T. L. Hissong

S7-20

M. R. Koch

S7-24

T. C. Mackey

R3-83

S. H. Rifaey

T4-07

P. D. Rhodes

R3-83

R. D. Smith

R $1-49$

D. H. Shuford

R3-83

M. C. Tipps

S7-24

W. E. Zuroff

S7-24

C. E. HAMPTON

58.09

Cogema Engineering Corporation

P. J. Fuller

R3-83

Dist-1 